\title{
5 GHZ WI-FI EFFECTS ON ESCHERICHIA COLI, CAENORHABDITIS ELEGANS AND HUMAN NEUROBLASTOMA CELLS
}

Bircan DİNÇ, Department of Biophysics, Faculty of Medicine, Bahçeşehir University, Turkey bircan.dinc@med.bau.edu.tr

(iD) https://orcid.org/0000-0002-9717-6410)

Muhammad ILYAS, Department of Electrical and Electronics Engineering, Faculty of Engineering and Natural Sciences, Altınbaş University, Turkey, muhammad.ilyas@altinbas.edu.tr

(iD) https://orcid.org/0000-0002-3207-451X)

Hakan KAYGUSUZ*, Department of Basic Sciences, School of Engineering and Natural Sciences, Altınbaş University, Turkey, hakan.kaygusuz@altinbas.edu.tr

(iD) https://orcid.org/0000-0001-9336-1902)

Osman Nuri UÇAN, Department of Electrical and Electronics Engineering, Faculty of Engineering and Natural Sciences, Altınbaş University, Turkey, osman.ucan@altinbas.edu.tr (iD) https://orcid.org/0000-0002-4100-0045)

Received: 04.11.2020, Accepted: 04.02.2021

Research Article

*Corresponding author DOI: $10.22531 /$ muglajsci.820783

\section{Abstract \\ The use of $5 \mathrm{GHz}$ Wi-Fi has spread and potential effects on microorganisms and human health are still under investigation. To investigate the possible effects for that, experiments were performed using three different microorganisms, Escherichia coli, SH-SY5Y human neuroblastoma cells and Caernohabditis elegans. The maximum allowed temperature for the Wi-Fi Access Point (AP) was considered in the measurement setup in order not to harm the internal circuitry of the router which can result impact the performance of the router. Suspension turbidity, optical density measurements and simultaneous counting of E. coli were performed. It was observed that $5 \mathrm{GHz} W$-Fi exposure slow down the E. coli growth rate at the same temperature conditions with sham exposed groups especially after the first 6 h. $5 \mathrm{GHz}$ Wi-Fi induced decrease in cell viability remarkably for the cells seeded at densities 20,40, $100\left(\times 10^{3}\right)$ and viability values were varied between 20 and 30\%. C. elegans which is a nematode, plays key role in nutrient cycling and soil fertilization was affected by the radiation and egg-laying rates changed by $27.49 \%$. \\ Keywords: 5 GHz Wi-Fi, C. elegans, E. coli, SH-SY5Y Cell \\ 5 GHZ KABLOSUZ AĞ DALGALARININ ESCHERICHIA COLI, CAENORHABDITIS ELEGANS VE İNSAN NÖROBLASTOM HÜCRELERINE ETKISİ}

Özet

$5 \mathrm{GHz}$ kablosuz internet bağlantılarının yaygınlaşmasıyla, bu dalgaların mikroorganizmalar ve insan sağlı̆̆ı üzerindeki etkileri halen incelenmektedir. Bu çalışmada, adı geçen dalgaların sağlığa etkisinin görülmesi amacıyla üç farklı mikroorganizma; Escherichia coli, Caernohabditis elegans ve SH-SY5Y insan nöroblastom hücreleri incelenmiștir. Denemelerde, aygıta zarar vermemek ve sinyal üretimine engel olmamak için kablosuz ağ bağlantı noktasının kullanılabilecek en yüksek sıcaklığı kullanılmıştır. Örneklerin süspansiyon türbiditesi, optik yoğunluğu ve eş zamanlı hücre sayımı yapılmıştır. Sonuçlara göre $5 \mathrm{GHz}$ kablosuz ağ dalgaları E. coli için çoğalma hızını özellikle 6. saatten sonra düşürmektedir ve nöroblastom hücreleri için yaşayabilme oranı \%20 ile \%30 arasındadır. Dahası, C. elegans gibi besin döngüsü ve toprağın doğal gübrelemesinde önemli bir rol oynayan ipliksisolucanın yumurta bırakma yüzdesi $27.49 \%$ oranında düşmüştür.

Anahtar Kelimeler: 5 GHz kablosuz ağ, C. elegans, E. coli, SH-SY5Y hücreleri

Cite

Dinç, B., Ilyas, M., Kaygusuz, H., Uçan, O. N. (2021). “5 GHz Wi-Fi effects on Escherichia coli, Caenorhabditis Elegans and human neuroblastoma cells", Mugla Journal of Science and Technology, 7(1), 7-13.

\section{Introduction}

The advancements of technology help human to live a comfortable life, by performing multiple tasks quickly, easily and with an ease of access to the required information. When new technologies and applications are first introduced, potential health risks are often neglected by mainly focusing on their positive outcomes. One of the best examples of this rapid adaptation of technology is wireless technology. Wireless communication enables people communicate regardless of their location and two or more devices to 
communicate with each other faster. On the other hand, in order to meet the demand for capacity, bandwidth and higher data rates, the number of Base Stations (BS's) are increased and new frequency spectrums are introduced for commercial use. This has resulted in the continuous exposure of these frequencies, especially in cities. [1]

$5 \mathrm{GHz}$ frequency spectrum operate in a bandwidth of 20 $\mathrm{MHz}$ for non-overlapping channels. That high bandwidth gives us the ability to transfer more information but with a cost of decrease in coverage area. It is noticed that the higher the frequencies of a wireless signal, the shorter is its range [2]. With the increase in the exposure to $5 \mathrm{GHz} \mathrm{Wi}-\mathrm{Fi}$, its effects on health have started to be more intriguing. Numerous research groups offer different results on this subject.

Even the 2.4 GHz Wi-Fi frequency caused degeneration in the mouse liver, brain and lung [3] Since the $2.4 \mathrm{GHz}$ frequency is no longer sufficient due to the increase in demand, the $2.4 \mathrm{GHz}$ reaches to its saturation point. This leads to the increasing demand for new spectrum and directed the communication engineers towards $5 \mathrm{GHz}$ frequency [4]. The fifth-generation $\mathrm{Wi}-\mathrm{Fi}$ is expected to become widespread in the near future and we can see multiple AP's operating on those frequencies [5]. Evolution of current $5 \mathrm{GHz}$ Wi-Fi technology will reach much higher radio frequencies (RF) such as $60 \mathrm{GHz}$ [6]. The higher frequencies may cause some changes in the biological structure and function due to the exposure to $\mathrm{RF}$ radiation (RFR) from multiple base stations operating on multiple frequencies every few meters. In the scientific literature, it is seen that the effects of wireless networks on health are examined and there are contradictory and supportive results [7].

In a study to confirm the harmful effects, mice and blood biochemistry of mice exposed to RFR for 8 hours a day at a distance of 1 meter for 6 months revealed degeneration of some cells [3]. The cancer risk of RFR was also published in 2011 by the International Agency for Research on Cancer (IARC) and categorized RFR as human carcinogen [8] Some studies reported that 2.4 GHz RFR damages reproductive cells in mice [9] and damages mouse brain cells after 1year by performing the detailed examination [10].

In general, high frequency is known to have an adverse effect on the bacterial population [11]. There are devices developed directly for this purpose and used for sterilization. In fact, bioelectric effect on bacteria has long been known $[12,13]$. This has shown that the electrical current supplied to the bacterial environment causes a significant decrease in the population of bacteria, particularly in the presence of antibiotic molecules. The effect of $10 \mathrm{MHz}$ frequency waves on bacterial biofilms was increased antibiotic efficacy. The mechanism in this investigation is basically explained by the fact that electric current or radio waves "vibrate the bacterial matrix, disrupting its integrity and facilitating the passage of antibiotic molecules" [14,15]]. In addition to this mechanism, it is interesting to note that electric current / radio waves can also produce by-products that disrupt the integrity of bacteria. Stewart et al. found that the oxygen produced in the presence of electric current / radio wave has lethal effects on bacteria [16].

Studies with different proofs show that radiofrequency radiation increases oxidative stress in cells, induces apoptosis and causes DNA damage [17]. There are also studies linking long-term exposure to Wi-Fi with an increase in migraine headaches [18]. To the best of authors knowledge there has been no study so far to evaluate the $5 \mathrm{GHz}$ Wi-Fi effect in human neuroblastoma cells.

Differently cell and bacteria assays, Caenorhabditis elegans (C. elegans) may be an experimental model to track the results of RFR exposure in an organism. $C$. elegans is a model organism, feeds on bacteria and an alternative to mammalian assays because it is an easier experimental model with its completely sequenced genome, having neuronal, motor, digestive, reproductive system, transparent tissues and good correlation of endpoint tests [19].

In this study, the effects of $5 \mathrm{GHz}$ frequency radiation on bacteria, human neuroblastoma cells and reproductive system of $C$. elegans were investigated. It is intended to examine the effect of the proliferation and viability and egg-laying rate of the bacteria, cells and $C$. elegans respectively. Gram-negative bacteria Escherichia coli (E. coli), which is a common model for several studies, and is pathogenic strains of this bacteria is dangerous at fecal-oral transmission route for humans, was selected as the model bacteria. SH-SY5Y cells were selected as invitro modeling of neuronal function because these cells have neuron-like phenotype and they are afforded numerous benefits in the field of neuroscience research. Wild type (N2) C. elegans was used in the study to focus on to determine if it changes the egg laying rates.

\section{Material and Methods}

E. coli (ATCC: 25922) were cultured for growth rate experiments. Mueller-Hinton agar was used for minimum bactericidal concentration (MBC) studies. SHSY5Y cells were cultured in DMEM F12 supplemented with $10 \%$ fetal bovine serum, 2 mM glutamine, 1\% nonessential amino acids, $1 \%$ penicillin streptomycin under standard conditions of temperature $\left(37^{\circ} \mathrm{C}-5 \% \mathrm{CO}_{2}\right)$.

\subsection{Experimental Design}

Exposed and sham exposed (control) bacteria, cells and C. elegans were at the same temperature conditions. Exposed groups were hold in Faraday cage in order to prevent radiation exposure and the temperature were kept at $37^{\circ} \mathrm{C}$ for bacteria and cells, $21^{\circ} \mathrm{C}$ for C.elegans in order to model body and soil growth temperatures, respectively. 


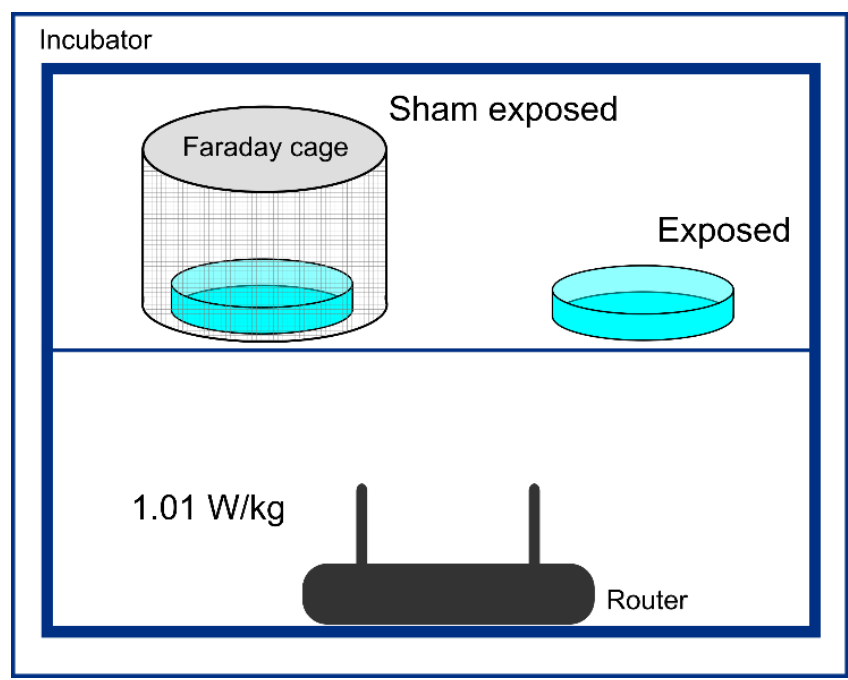

Figure 1. Experimental design of exposed and sham exposed groups

\subsection{Bacterial Growth Experiments}

Suspensions of E. coli were prepared in triplicate (3 for exposed, 3 for sham exposed) as 0.5 McFarland Standard in a densitometer (Biosan DEN-1 McFarland). Then, E. coli was brought up in bacterial agar $(10 \mathrm{~mL})$ for 1 day at $37{ }^{\circ} \mathrm{C}$ and bacterial growth curves were obtained considering the optical density at $625 \mathrm{~nm}$, simultaneous densitometer measurements were taken. Density was measured at $3 \mathrm{~h}$ intervals for the first 12 hours. After that the last measurement was taken at 24 th $\mathrm{h}$ with densitometer $(\lambda=565 \pm 15 \mathrm{~nm})$. Experiments were repeated three times independently from each other.

\subsection{Cell Viability and DAPI Staining}

Cells were seeded 6, 24 well plates at different cell densities $\left(20,40,100 \times 10^{3}\right)$ and 72 hours later, MTT (3[4,5-dimethylthiazol-2-yl]-2,5-diphenyl tetrazolium bromide) assay procedure was applied and absorbance values measured at $550 \mathrm{~nm}$. After $72 \mathrm{~h}$ incubation of $100 \times 10^{3}$ cells in 6 well plates that have cover slips at the bottom and at the same conditions similar to viability assays (Figure 1), cells were fixed 3\% paraformaldehyde for $15 \mathrm{~min}$ after each treatment and stained with 4',6-diamidino-2-phenylindole (DAPI), monitored under a confocal microscope (Leica DM 5500) for morphological change. Invert microscope (Leica MC120) images were taken at 10X magnification.

\subsection{C.elegans egg hatching}

$\mathrm{N} 2$ type C. elegans was maintained at $21{ }^{\circ} \mathrm{C}$ on Nematode Growth Medium (NGM) petri dishes (100 $\mathrm{mm}$ ) with E. coli OP50 bacteria as a food source. Synchronous populations were generated by hypochlorite- $\mathrm{NaOH}$ treatment after collecting adult worms by pipetting distilled water. The isolated embryos raised on NGM culture plates. After L1 stage of isolated embryos, they were incubated with router up to reaching young adult stage for egg laying. After egg- laying started, adults were collected $5 \mathrm{~h}$ later. After all the eggs reached the L1 larva stage $(\sim 15 \mathrm{~h})$, the worms were scanned by high resolution scanner (EPSON V800) and counted (Figures. 2 and 3).

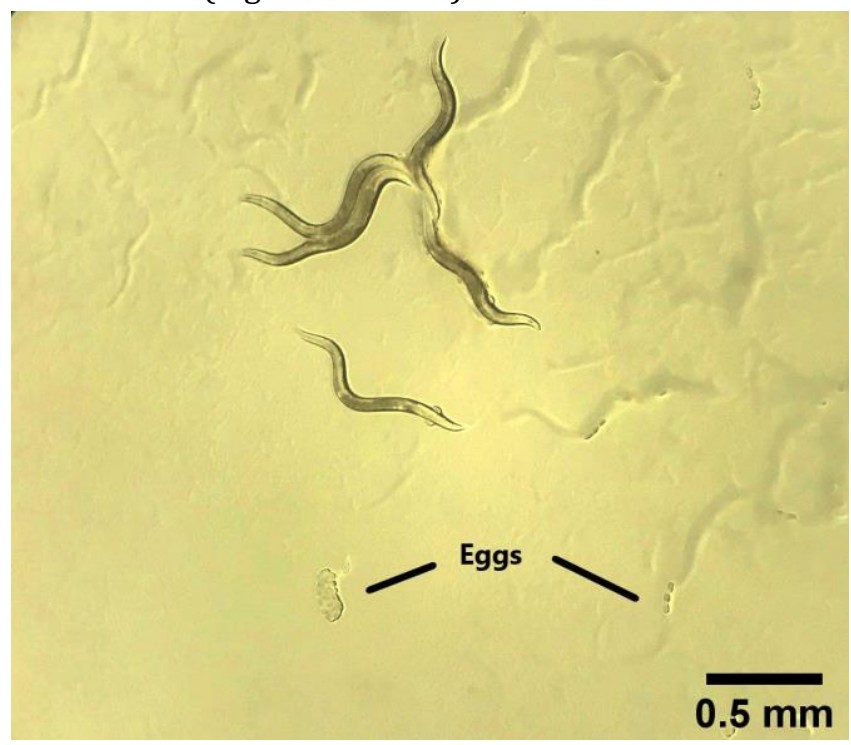

Figure 2. Young adult C. elegans and eggs

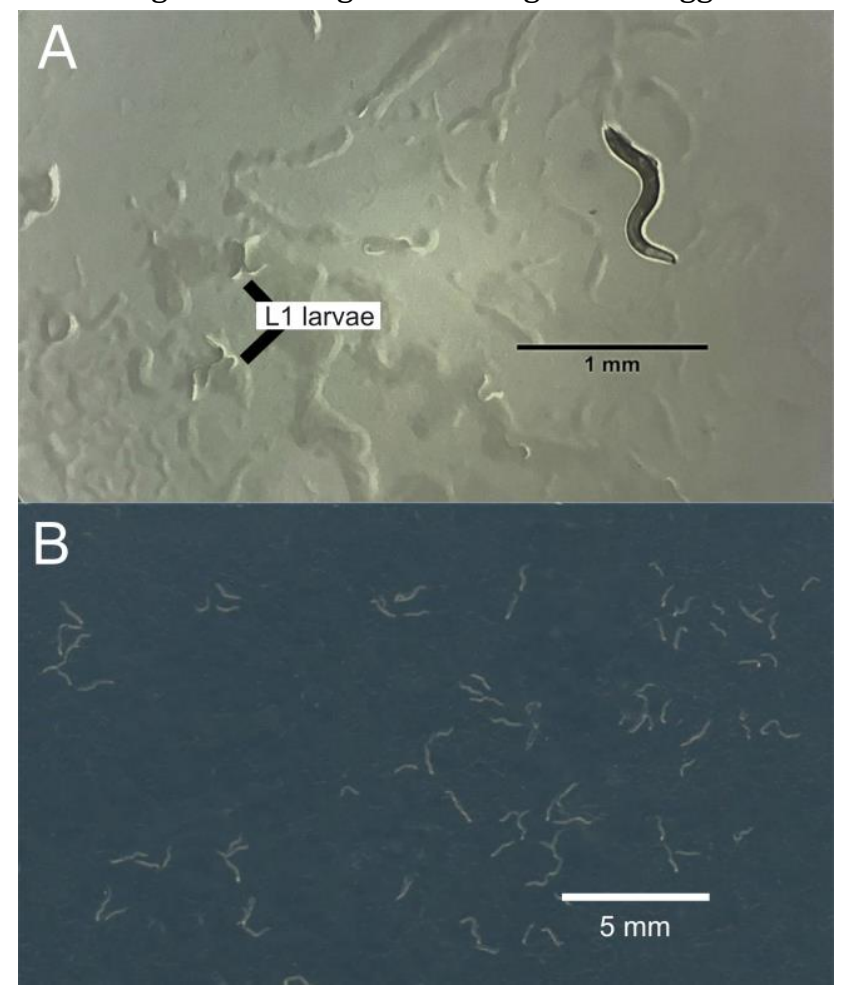

Figure 3. A) After egg laying reaching the L1 stage, B) Scanned L1 stage nematodes

\subsection{Statistical Analysis}

Optical density and suspension turbidity and bacteria counting values and cell viability values, $C$. elegans egg laying rate averages were subjected to t test and $\mathrm{p}<0.01$ $\& \mathrm{p}<0.05$ (IBM SPSS Statistiscs 22). 


\section{Results and Discussion}

Resistance of bacteria to antibiotics is one of the important problems of our time. Studies have shown that bacteria exposed to $\mathrm{Wi}$-Fi gain antibiotic resistance and their growth rates decrease compared to control groups $[20,21]$. Investigating whether it has a similar enhancing effect on viruses is also very important these days when we are dealing with COVID-19. An extensive literature is needed to support the views of different research groups on the subject. We are exposed to more Wi-Fi at the same time from many different sources. While $5 \mathrm{GHz}$ Wi-Fi have advantages like effectiveness, efficiency, high resolution and bi-directional bandwidth shaping, further studies are needed for potential hazards.

In this study, we have investigated E. coli growth rate, SH-SY5Y cell viability and C. elegans egg-laying rate when they exposed to $5 \mathrm{GHz}$ Wi-Fi waves for up to 24, $72,70 \mathrm{~h}$ respectively. According to $24 \mathrm{~h}$ growth rate change for E. coli (Figure 4 and 5), Wi-Fi exposed bacteria showed similar growth rate in the first $6 \mathrm{~h}$. However, there was a meaningful change in rates of exposed and sham exposed bacteria growth rates after 6 hours exposure up to 24th h. It is important to note that until 6 hours the values are statistically same and indicates that short term exposure of Wi-Fi is not effective enough to change the growth rate.

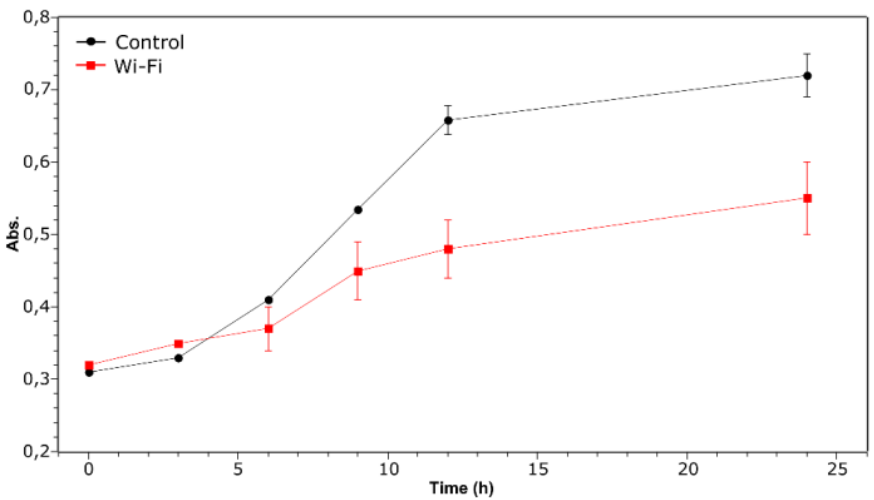

Figure 4. Optical density of E. coli $(p<0.05)$

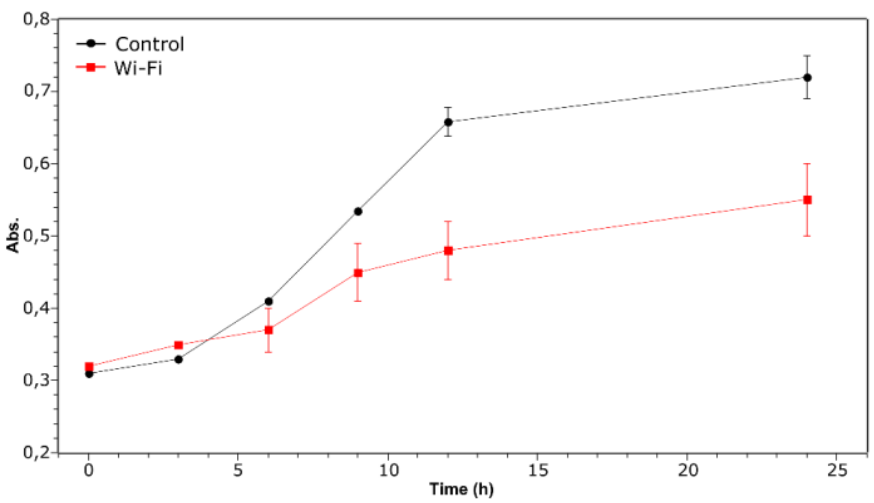

Figure 5. Suspension turbidity of E. coli $(\mathrm{p}<0.05)$

When bacteria are exposed to $2.4 \mathrm{GHz}$ Wi-Fi for a long time, it has been shown to affect the growth of bacteria [20]. In our study, the growth of E. coli (25922) after $6 \mathrm{~h}$ exposure was negatively affected from the $5 \mathrm{GHz}$ Wi-Fi that corrects long term exposure results of previous studies [22,23].

SH-SY5Y cells have been used for in vitro studies of neurodegenerative disorders. Here, the long-term effects of $5 \mathrm{GHz}$ Wi-Fi on cell viability and morphological changes were detected (Figure 6 A, B). In the images obtained after 24-hour exposure, there was no difference in cell shapes in exposed and sham exposed groups, but there were localized decreases in adherent cell distributions for sham exposed groups (Figure 7 A, B).

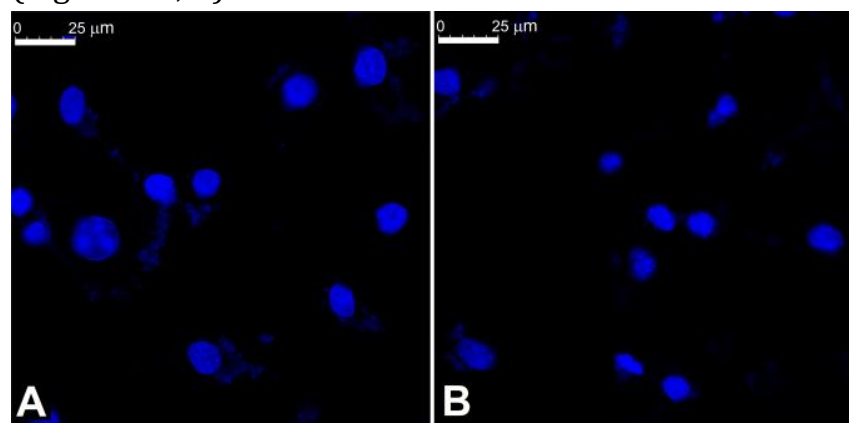

Figure 6. A-SH-SY5Y sham exposed cells by DAPI staining; B- Wi-Fi exposed cells by DAPI staining

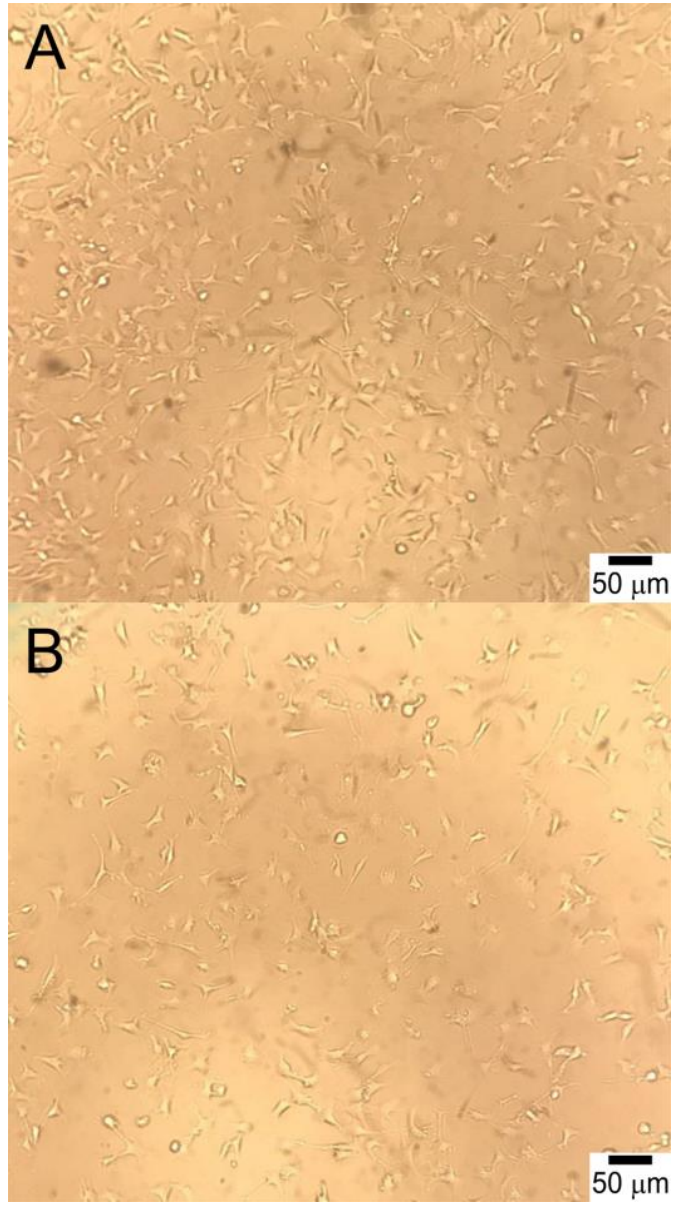

Figure 7. A) Control SH-SY5Y cell density, B) Wi-Fi exposed SH-SY5Y cells $24 \mathrm{~h}$ exposure

In viability tests with different numbers of cells, it was observed that the change in viability in cells was not at the same rate. Experiments with 20, 40 and $100\left(\times 10^{3}\right)$ 
seeded cells showed changes in viability ranging from 20-30\% (Figure 8-A) after $72 \mathrm{~h}$ exposure. Previous studies report that radio frequency radiation indirectly effect cell membrane, translation of RNA, DNA damage and inducing oxidative stress [24,25]. DAPI nuclear staining was showed more regular and oval shape of sham exposed cells. Morphological changes of E. coli and cochlear stria marginal cells were reported before for extremely low frequency $(<300 \mathrm{~Hz})$ and $1800 \mathrm{MHz}$ radiofrequency radiation $[17,26]$.

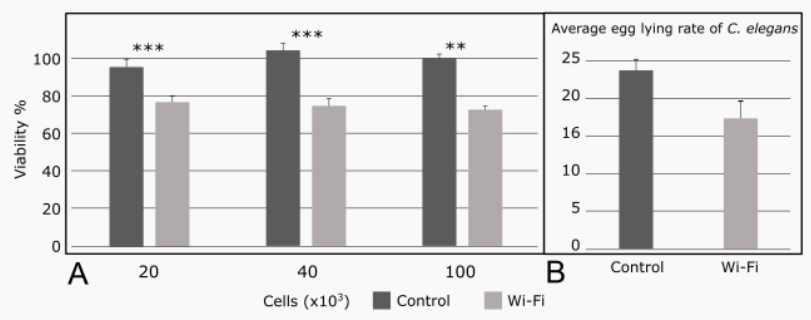

Figure 8. A) \% Viability of different number SH-SY5Y cells ( $\left.\left.{ }^{* * *} \mathrm{p}<0.01,{ }^{* *} \mathrm{p}<0.05\right), \mathrm{B}\right)$ Average number of eggs for every adult $(\mathrm{P}<0.01)$

It has been described that even Wi-Fi waves of less than $5 \mathrm{GHz}$ in different cell lines cause oxidative stress in cells [10]. It has also been reported to cause apoptosis, neurological effects, poor sperm quality, morphological changes of sperms and DNA damage in the cell $[25,27,28]$.

While the health effects of high frequency electromagnetic waves continue to be discussed [29], research into the effects on different cell lines and bacteria is gaining importance. Although there are important studies claiming to have no impact on human health [30]], there are also research groups that draw attention to the potential hazard with experimental results [31].

C. elegans population can has some roles on nutrient cycle and fertilization of soil [32]. We know that there are contradictory results in cells and bacteria exposed to RFR when studies by different research groups are examined [33,34]. A similar situation is also valid for $\mathrm{C}$. elegans exposed to radiofrequency. For C. elegans, which are exposed to non-thermal electromagnetic waves, induced some changes such as conformational damages to cellular proteins, opposite effects on growth and egg production [35]. In an opposite-minded research, after prolonged exposure to $1750 \mathrm{MHz} \mathrm{RF}$ fields, no effect was observed on longevity and development of C. elegans [36]. No significant differences were reported by another research group between exposed and sham exposed groups for lifespan, fertility, growth, memory, ROS, apoptosis or gene expression of C. elegans [37].

$5 \mathrm{GHz}$ Wi-Fi exposed L1 larvae were evaluated for egglaying rate after reaching young adult stage, when embryos of the young adults reached L1 stage again, adults were collected and L1 larvae were counted. According to egg production rate differences between exposed and sham exposed groups, there is a significant decrease in the egg production (Figure 8-B). The reason for the decrease may be RF-induced stress [38] or nonthermal RF induced heat-shock $[35,39,40]$ and this is an important area to investigate. Because, being affected by high frequency RFR of $C$. elegans egg laying rate as a member of nutrient cycle and indirect soil fertilizer, it may also disrupt the natural balance of life in regions exposed to high frequency waves up to $100 \mathrm{GHz}$ or beyond for a long time. Long term exposure of high frequency RFR can even change yield of soil due to the effects on soil microorganisms.

In our study, we intend to see the $5 \mathrm{GHz}$ Wi-Fi effects on the growth rate of bacteria and the effect of viability in SH-SY5Y cells that have not been exposed to such a high frequency radio waves in previous studies.

\section{Conclusion}

In this study, negative effect of $5 \mathrm{GHz}$ frequency on bacteria, neuroblastoma cells and C. elegans was reported by the means of the decrease of growth rate, viability and egg laying rate after long term exposure. When exposed to radiofrequency radiation, the growth rate of bacteria decreased by up to $20 \%$. A decrease in viability and deformed nuclei were observed in SH-SY5Y cells after 72 hours of exposure. We have reported an easily measurement technique and significant biological effect of $5 \mathrm{GHz}$ Wi-Fi exposure on $C$. elegans, suggesting variety of approaches for the effects of high frequency RFR on plasma membrane, subcellular compartments, and exact mechanisms of interaction between RFR and living organisms.

\section{References}

[1] Simkó, M. and Mattsson, M.0., "5G wireless communication and health effects - A pragmatic review based on available studies regarding 6 to $100 \mathrm{GHz}$, International Journal of Environmental Research and Public Health, 16(18), 3406, 2019.

[2] Perahia, E. and Gong, M.X., "Gigabit wireless LANs: an overview of IEEE 802.11 ac and 802.11 ad", ACM SIGMOBILE Mobile Computing and Communications Review, 15(3), 23-33, 2011.

[3] Ishak, N.H., Ariffin, R., Ali, A., Sagiruddin, M.A. and Tawi, F.M.T., "Biological effects of WiFi electromagnetic radiation", Proceedings - 2011 IEEE International Conference on Control System, Computing and Engineering, ICCSCE 2011, 2011, pp. 551-556

[4] Naik, G., Liu, J. and Park, J.M.J., "Coexistence of wireless technologies in the $5 \mathrm{GHz}$ bands: A survey of existing solutions and a roadmap for future research", IEEE Communications Surveys and Tutorials, 20(3), 1777-1798, 2018.

[5] Hardell, L., Carlberg, M. and Hedendahl, L.K., "Radiofrequency radiation from nearby base stations gives high levels in an apartment in Stockholm, Sweden: A case report", Oncology Letters, 15(5), 7871-7883, 2018. 
[6] Di Ciaula, A., "Towards 5G communication systems: Are there health implications?", International Journal of Hygiene and Environmental Health, 221(3), 367-375, 2018.

[7] Jurčević, M. and Malarić, K., "Assessment of Wi-Fi radiation on human health." 2016 24th International Conference on Software, Telecommunications and Computer Networks, SoftCOM 2016, Institute of Electrical and Electronics Engineers Inc., 2016.

[8] Hardell, L., "World health organization, radiofrequency radiation and health - A hard nut to crack (Review)", International Journal of Oncology, 51(2), 405-413, 2017.

[9] Atasoy, H.I., Gunal, M.Y., Atasoy, P., Elgun, S. and Bugdayci, G., "Immunohistopathologic demonstration of deleterious effects on growing rat testes of radiofrequency waves emitted from conventional Wi-Fi devices", Journal of Pediatric Urology, 9(2), 223-229, 2013.

[10] Dasdag, S., Akdag, M.Z., Erdal, M.E., Erdal, N., Ay, O.I., Ay, M.E., Yilmaz, S.G., Tasdelen, B. and Yegin, K., "Effects of $2.4 \mathrm{GHz}$ radiofrequency radiation emitted from Wi-Fi equipment on microRNA expression in brain tissue", International Journal of Radiation Biology, 91(7), 555-561, 2015.

[11] Wietzikoski Lovato, E.C., Gurgel Velasquez, P.A., dos Santos Oliveira, C., Baruffi, C., Anghinoni, T., Machado, R.C., Lívero, F.A. dos R., Sato, S.W. and Martins, L. de A., "High frequency equipment promotes antibacterial effects dependent on intensity and exposure time", Clinical, Cosmetic and Investigational Dermatology, 11, 131-135, 2018.

[12] Khoury, A.E., Lam, K., Ellis, B. and Costerton, J.W., "Prevention and control of bacterial infections associated with medical devices", ASAIO Journal, 38(3), M174-8, 1992.

[13] Blenkinsopp, S.A., Khoury, A.E. and Costerton, J.W., "Electrical enhancement of biocide efficacy against Pseudomonas aeruginosa biofilms", Applied and Environmental Microbiology, 58(11), 3770-3773, 1992.

[14] Caubet, R., Pedarros-Caubet, F., Chu, M., Freye, E., De Belém Rodrigues, M., Moreau, J.M. and Ellison, W.J., "A radio frequency electric current enhances antibiotic efficacy against bacterial biofilms", Antimicrobial Agents and Chemotherapy, 48(12), 4662-4664, 2004.

[15] Rediske, A.M., Roeder, B.L., Brown, M.K., Nelson, J.L., Robison, R.L., Draper, D.O., Schaalje, G.B., Robison, R.A. and Pitt, W.G., "Ultrasonic enhancement of antibiotic action on Escherichia coli biofilms: An in vivo model", Antimicrobial Agents and Chemotherapy, 43(5), 12111214, 1999.

[16] Stewart, P.S., Wattanakaroon, W., Goodrum, L., Fortun, S.M. and McLeod, B.R., "Electrolytic generation of oxygen partially explains electrical enhancement of tobramycin efficacy against Pseudomonas aeruginosa biofilm", Antimicrobial Agents and Chemotherapy, 43(2), 292-296, 1999.
[17] Yang, H., Zhang, Y., Wang, Z., Zhong, S., Hu, G. and Zuo, W., "The Effects of Mobile Phone Radiofrequency Radiation on Cochlear Stria Marginal Cells in SpragueDawley Rats", Bioelectromagnetics, 41(3), 219-229, 2020.

[18] Mohammadianinejad, S.E., Babaei, M. and Nazari, P., "The Effects of Exposure to Low Frequency Electromagnetic Fields in the Treatment of Migraine Headache: A Cohort Study", Electronic physician, 8(12), 3445-3449, 2016.

[19] Hunt, P.R., "The C. elegans model in toxicity testing", Journal of Applied Toxicology, 37(1), 50-59, 2017.

[20] Taheri, M., Mortazavi, S.M.J., Moradi, M., Mansouri, S., Hatam, G.R. and Nouri, F., "Evaluation of the effect of radiofrequency radiation emitted from Wi-Fi router and mobile phone simulator on the antibacterial susceptibility of pathogenic bacteria listeria monocytogenes and Escherichia coli", Dose-Response, 15(1), 1559325816688527, 2017.

[21] Said-Salman, I.H., Jebaii, F.A., Yusef, H.H. and Moustafa, M.E., "Evaluation of Wi-Fi Radiation Effects on Antibiotic Susceptibility, Metabolic Activity and Biofilm Formation by Escherichia Coli 0157H7, Staphylococcus Aureus and Staphylococcus Epidermis", Journal of Biomedical Physics and Engineering, 9(5), 579-586, 2019.

[22] Nakouti, I., Hobbs, G., Teethaisong, Y. and Phipps, D., "A demonstration of athermal effects of continuous microwave irradiation on the growth and antibiotic sensitivity of Pseudomonas aeruginosa PA01", Biotechnology Progress, 33(1), 37-44, 2017.

[23] Salmen, S.H., Alharbi, S.A., Faden, A.A. and Wainwright, M., "Evaluation of effect of high frequency electromagnetic field on growth and antibiotic sensitivity of bacteria", Saudi Journal of Biological Sciences, 25(1), 105-110, 2018.

[24] Diem, E., Schwarz, C., Adlkofer, F., Jahn, O., and Rüdiger, H., "Non-thermal DNA breakage by mobilephone radiation $(1800 \mathrm{MHz})$ in human fibroblasts and in transformed GFSH-R17 rat granulosa cells in vitro", Mutation Research - Genetic Toxicology and Environmental Mutagenesis, 583(2), 178-183, 2005.

[25] Akdag, M.Z., Dasdag, S., Canturk, F., Karabulut, D., Caner, Y. and Adalier, N., "Does prolonged radiofrequency radiation emitted from Wi-Fi devices induce DNA damage in various tissues of rats?", Journal of Chemical Neuroanatomy, 75, 116-122, 2016.

[26] Inhan-Garip, A., Aksu, B., Akan, Z., Akakin, D., Ozaydin, A.N. and San, T., "Effect of extremely low frequency electromagnetic fields on growth rate and morphology of bacteria", International Journal of Radiation Biology, 87(12), 1155-1161, 2011.

[27] Hassanshahi, A., Shafeie, S.A., Fatemi, I., Hassanshahi, E., Allahtavakoli, M., Shabani, M., Roohbakhsh, A. and Shamsizadeh, A., "The effect of WiFi electromagnetic waves in unimodal and multimodal 
object recognition tasks in male rats", Neurological Sciences, 38(6), 1069-1076, 2017.

[28] Shokri, S., Soltani, A., Kazemi, M., Sardari, D. and Babapoor Mofrad, F., "Effects of Wi-Fi (2.45 GHz) exposure on apoptosis, sperm parameters and testicular histomorphometry in rats: A time course study", Cell Journal, 17(2), 322-331, 2015.

[29] Pall, M.L., "Wi-Fi is an important threat to human health", Environmental Research, 164, 405-416, 2018.

[30] Foster, K.R. and Moulder, J.E., "Wi-Fi and health: Review of current status of research", Health Physics, 105(6), 561-575, 2013.

[31] Çĭg, B. and Naziroğlu, M., "Investigation of the effects of distance from sources on apoptosis, oxidative stress and cytosolic calcium accumulation via TRPV1 channels induced by mobile phones and Wi-Fi in breast cancer cells", Biochimica et Biophysica Acta Biomembranes, 1848(10), 2756-2765, 2015.

[32] Zečić, A., Dhondt, I. and Braeckman, B.P., "The nutritional requirements of Caenorhabditis elegans", Genes and Nutrition, 14(1), 15, 2019.

[33] Fojt, L., Klapetek, P., Strašák, L. and Vetterl, V., "50 $\mathrm{Hz}$ magnetic field effect on the morphology of bacteria", Micron, 40(8), 918-922, 2009.

[34] Cellini, L., Grande, R., Di Campli, E., Di Bartolomeo, S., Di Giulio, M., Robuffo, I., Trubiani, O. and Mariggiò, M.A., "Bacterial response to the exposure of $50 \mathrm{~Hz}$ electromagnetic fields", Bioelectromagnetics, 29(4), 302-311, 2008.

[35] De Pomerai, D.I., Dawe, A., Djerbib, L., Allan, J., Brunt, G. and Daniells, C., "Growth and maturation of the nematode Caenorhabditis elegans following exposure to weak microwave fields", Enzyme and Microbial Technology, 30(1), 73-79, 2002.

[36] Gao, Y., Lu, Y., Yi, J., Li, Z., Gao, D., Yu, Z., Wu, T. and Zhang, C., "A genome-wide mRNA expression profile in caenorhabditis elegans under prolonged exposure to $1750 \mathrm{MHz}$ radiofrequency fields", PLOS ONE, 11(1), e0147273, 2016.

[37] Fasseas, M.K., Fragopoulou, A.F., Manta, A.K., Skouroliakou, A., Vekrellis, K., Margaritis, L.H. and Syntichaki, P., "Response of Caenorhabditis elegans to wireless devices radiation exposure", International Journal of Radiation Biology, 91(3), 286-293, 2015.

[38] Daniells, C., Duce, I., Thomas, D., Sewell, P., Tattersall, J. and De Pomerai, D., "Transgenic nematodes as biomonitors of microwave-induced stress", Mutation Research - Fundamental and Molecular Mechanisms of Mutagenesis, 399(1), 55-64, 1998.

[39] Junkersdorf, B., Bauer, H. and Gutzeit, H.O., "Electromagnetic fields enhance the stress response at elevated temperatures in the nematode Caenorhabditis elegans", Bioelectromagnetics, 21(2), 100-106, 2000.

[40] Gul Guven, R., Guven, K., Dawe, A., Worthington, J., Harvell, C., Popple, A., Smith, T., Smith, B. and de Pomerai, D.I., "Effects of radio-frequency fields on bacterial cell membranes and nematode temperaturesensitive mutants", Enzyme and Microbial Technology, 39(4), 788-795, 2006. 